\title{
Investigating Catalase and Carbonic Anhydrase Enzyme Activities and Levels of Certain Trace Elements and Heavy Metals in Patients with Primary and Metastatic Hepatic Carcinoma
}

\author{
Ayse Arslan $^{1 *}$, Halit Demir ${ }^{1}$, Harun Arslan ${ }^{2}$ \\ ${ }^{1}$ Department of Biochemistry, Faculty of Science, Yuzuncu Yil University, Van, Turkey; ${ }^{2}$ Radiology Department, Van Regional \\ Training and Research Hospital, Van, Turkey. \\ Email: *aysearslan@yyu.edu.tr \\ Received September $19^{\text {th }}, 2013$; revised October $15^{\text {th }}, 2013$; accepted October $23^{\text {rd }}, 2013$ \\ Copyright (C) 2013 Ayse Arslan et al. This is an open access article distributed under the Creative Commons Attribution License, \\ which permits unrestricted use, distribution, and reproduction in any medium, provided the original work is properly cited.
}

\begin{abstract}
Hepatocellular carcinoma (HCC) is among most common terminal cancer types in the world. Primary etiological factors include cirrhosis, hepatitis, aflatoxin and alcohol. The current study was conducted to determine cytosolic erythrocyte carbonic anhydrase and catalase enzyme activities and levels of some trace elements. For this purpose, 40 patients with primary and metastatic hepatic cancer and 29 healthy volunteers enrolled to the study. Catalase and carbonic anhydrase enzyme activities and serum trace element levels were measured in patient and control groups. In the current study, serum copper, magnesium, manganese and zinc levels were lower in the primary and metastatic hepatic cancer group in comparison with the control group $(\mathrm{P}<0.05)$. In contrast, serum iron, cobalt, cadmium and lead levels were higher in the patient relative to the control group $(\mathrm{P}<0.05)$. In comparison with the control group, the catalase level was lower in primary and metastatic cancer group, while the carbonic anhydrase level was higher in the cancer group $(\mathrm{P}<0.05)$. Changes in levels of trace elements and anti-oxidant enzymes may be the factors which influence the development and progression of liver cancer. The carbonic anhydrase enzyme can be a useful indicator in the diagnosis of cancer. However, this issue warrants further investigation.
\end{abstract}

Keywords: Primary and Metastatic Liver Cancer; Catalase; Carbonic Anhydrase; Trace Element; Heavy Metal

\section{Introduction}

Hepatic carcinoma is one of common solid cancers, which leads to the death of 650,000 people per year worldwide [1]. The most significant risk factor of hepatic cancer is liver cirrhosis. It accounts for $90 \%$ of hepatic carcinoma cases. In addition, important risk factors include chronic viral hepatic infections (HBV-Hepatitis B and HCV-Hepatitis C), alcohol, aflatoxin, intoxications and genetic diseases such as hemochromatosis and diabetes $[1,2]$.

Hepatic tumors are divided into three groups, includeing primary benign, primary malignant and secondary (metastatic) tumors. The ratio of primary and metastatic tumor is $1 / 20$. Primary hepatic cancers are usually divided into two groups. If the tumor originates from hepatocytes, it is referred to as hepatocellular carcinoma (HCC), while the term is cholangiocellular carcinoma

\footnotetext{
*Corresponding author.
}

(CCC) if it is derived from intra-hepatic bile ducts. HCC accounts for $90 \%$ of primary hepatic carcinomas, while CCC accounts for 10 percent of all liver cancer cases $[3,4]$.

Hydrogen peroxide $\left(\mathrm{H}_{2} \mathrm{O}_{2}\right)$ is an oxidative agent, which is, in fact, a byproduct of some physiological processes, such as cellular respiration. Increases in oxidant molecules can be suppressed by natural anti-oxidant substances, which are normally found at particular levels in the body. Thus, the level of oxidants is balanced by the suppressive effect of anti-oxidant substance in a healthy organism [5]. Oxidative stress occurs if the sensitive balance between free radicals and the anti-oxidant defense mechanism is impaired and shifts in a manner favoring pro-oxidant and oxidant substances. It was demonstrated that oxidative stress causes tissue damage and it plays a role in the development of pathological conditions such as cancer, diabetes and atherosclerosis $[6,7]$. 
Catalase (CAT; E.C. 1.11.1.6) is an enzyme, which plays a role in oxidative stress by converting hydrogen peroxide to molecular oxygen $\left(\mathrm{O}_{2}\right)$ and water $\left(\mathrm{H}_{2} \mathrm{O}\right)$. Catalase activity is influenced by some physiological conditions and particular diseases, including cancer [5]. A decrease in the level of anti-oxidant substances may lead to cellular damage and malignant transformation, since the balance between pro-oxidant and anti-oxidant substances will impair [8].

Carbonic anhydrase (CA; E.C. 4.2.1.1) is a family of enzymes in the group of metallo-enzymes, which catalyze the conversion between $\mathrm{CO}_{2}$ and $\mathrm{HCO}_{3}^{-}$[9]. CAI and CAII are two enzymes which are abundant in erythrocytes, and in particularly, CAII has high activity [10]. Various studies had found that carbonic anhydrases played a role in malignant cerebral tumors and gastric and pancreatic cancers [11]. In malignant diseases, acidic extracellular fluid promotes the dissemination behavior of tumor [12]. It was suggested that hydration of $\mathrm{CO}_{2}$ into $\mathrm{H}_{2} \mathrm{CO}_{2}$, which is reversibly catalyzed by carbonic anhydrase iso-enzymes, plays a role in the acidity of extracellular fluid [13]. In the literature, there is no study examining erythrocyte $\mathrm{CA}$ level in hepatic cancer.

Trace elements are required for many metabolic and physiological events in the body. Therefore, the imbalance of trace element levels will adversely influence biological processes in vivo, resulting in the occurrence of various diseases. Epidemiological studies demonstrated that trace elements play a role in the etiology of many diseases, including cancer [14].

It was determined that some trace elements are related to the occurrence of HCC. For example, it was found that the incidence of HCC was 10 times higher in subjects with excess iron (without primary hemochromatosis) in comparison with normal subjects [15]. Although it is not clearly specified how Fe contributes to the occurrence and growth of cancer, the possible mechanism is that $\mathrm{Fe}$ leads to secondary damage in nucleic acids by promoting production of free oxygen radicals [16]. Similarly, copper is a predisposing factor in the occurrence of HCC, since it plays role in hepatic damage [17]. In combination with $\mathrm{Fe}, \mathrm{Cu}$ leads to production of free oxygen radicals, which damage cellular organelles. If copper levels increases (similar to iron), the production of highly reactive oxygen species increases, which lead to peroxidation of membrane lipids, direct oxidation of proteins and damage of DNA and RNA molecules [18]. In contrast, Zn alleviates pro-oxidative toxic effects, which are secondary to excess or insufficient intake of some substances, and thus, it produces a hepatoprotective effect [19]. A higher in vivo level of carcinogenic metals, such as lead and cadmium, may result in some physiological disorders. For example, cadmium is a strong carcinogenic sub- stance in humans and it was found that environmental exposure leads to cancer of the prostate, kidneys and pancreas, and in particular, the lungs [20]. Similarly, it was suggested that environmental exposure to lead is related to the occurrence of esophageal, hepatic and bladder cancers [21].

The current study was conducted to the determine serum levels of trace elements and heavy metals and to quantify the activity levels of erythrocyte catalase and carbonic anhydrase enzymes in patients with primary and metastatic hepatic cancer.

\section{Material and Method}

A total of 40 patients with hepatic cancer were enrolled in the current study and 29 healthy controls. In the study, blood samples were drawn from patients who were admitted to the Oncology Clinic of Training and Research Hospital, Medical Faculty, Yüzüncü Yll University and were diagnosed with cancer in the light of radiological and histopathological examinations, and from healthy subjects. Cancer patients and control subjects were similar in terms of age and gender. The mean age of cancer patients was $45-65$ years, and in this group, eight subjects were female and 32 subjects were male. Of the healthy subjects forming the control group, six were female and 23 were male, while the mean age was $48-65$ years. Considering histopathological tumors, it was determined that 14 patients had primary hepatic cancer, while 26 patients had metastatic hepatic cancer. Metastasis from various organs (esophagus, stomach, colon and small intestine) to the liver was determined in 26 subjects in the cancer group. Patients who were newly diagnosed and patients with a history of anti-cancer therapy were excluded. In the current study, approval was obtained from the Local Ethics Committee of Clinical and Laboratory Studies, Training and Research Hospital, Medical Faculty, Yüzüncü Y1l University, before blood samples were drawn. In addition, written consent was obtained from patients and healthy subjects before blood samples were drawn.

Venous blood sample of $7 \mathrm{ml}$ was drawn from each study subject, including healthy controls and patients. Serum was obtained by centrifuging the blood sample at $3500 \mathrm{rpm} / \mathrm{min}$ for 10 minutes and the plasma and buff coat were removed. Samples were stored at $-80^{\circ} \mathrm{C}$ until they were analyzed. Trace elements, minerals and heavy metals $(\mathrm{Pb}, \mathrm{Cd}, \mathrm{Mn}, \mathrm{Cu}, \mathrm{Mg}, \mathrm{Zn}, \mathrm{Fe}$ and $\mathrm{Co})$ were determine in serum samples of all study subjects with Atomic Absorption Spectrophotometer (AAS: UNICAM929 Spectrophotometer, Unicam Ltd., York Street, Cambridge, UK). Erythrocyte samples were prepared to measure catalase and carbonic anhydrase enzyme activities. 
Blood samples were added to EDTA (Ethylenedia-minetetracetate) tubes to prepare erythrocyte specimen and plasma was obtained by centrifuging samples at 3500 rpm for 10 minutes. Plasma was discarded and remaining part was irrigated with saline $(0.9 \% \mathrm{NaCl})$. Resultant upper phases were separated and discarded, and a pure erythrocyte pack was prepared by repeating this process three times. Carbonic anhydrase and catalase enzyme activities were analyzed in erythrocyte pack samples.

Carbonic anhydrase activity analysis was carried out according to the method, which was developed by Maren and colleagues [22]. This method is based on the principle of measuring time, which elapses to decrease $\mathrm{pH}$ from 10 to 7.4 due to $\mathrm{H}^{+}$ion released secondary to hydration of $\mathrm{CO}_{2}$. The indicator was phenol red since $\mathrm{pH}$ is associated with color change at $\mathrm{pH}=7.4$.

Activities were determined as follows: First, $2 \mathrm{ml}$ of indicator (phenol red) and $1.5 \mathrm{ml}$ of saturated $\mathrm{CO}_{2}$ solution were added into reaction tube. $\mathrm{CO}_{2}$ gas was passed from pure water at $0^{\circ} \mathrm{C}$ for half an hour in order to prepare a saturated $\mathrm{CO}_{2}$ solution). Enzyme solution $(0.1 \mathrm{ml})$ was added to this mixture. At the same time, $0.4 \mathrm{ml}$ of carbonate buffer was added to the solution and time was measured, which elapsed for conversion of red to yellow, and result was expressed as Tc. Pure water was added to the blank solution tube (rather than $0.1 \mathrm{ml}$ of enzyme solution) and the same procedures were repeated to determine To. In this method, for CA enzyme activity, one enzyme unit (EU) is defined as amount of enzyme which halves time of non-enzymatic $\mathrm{CO}_{2}$ hydration.

Using the formula $E U=\left(t_{o}-t_{c}\right) / t_{c}$, enzyme unit was analyzed in the volume of eluate used [22].

Catalase enzyme activity was measured according to Aebi method [23]. $\mathrm{H}_{2} \mathrm{O}_{2}$ was disintegrated and removed from the analysis environment and the resultant reduction of absorbance was read at $240 \mathrm{~nm}$. Activity was determined as follows. First, two tubes were made ready; 0.1 $\mathrm{ml}$ of enzyme (erythrocyte) was added to the first tube and pure water was placed into the second tube instead of erythrocyte and $2.8 \mathrm{ml}$ of phosphate buffer was added to both tubes. Next, $0.1 \mathrm{ml}$ of $\mathrm{H}_{2} \mathrm{O}_{2}$ was added to both tubes and they were vortexed. Activity was analyzed at 30second intervals for 3 minutes and next. The change in absorbance was monitored at $240 \mathrm{~nm}$ using a spectrophotometer (Shimadzu UV-1201, Japan).

Statistical Analysis: Parameters were expressed as mean \pm standard error (SE) and a $P$ value $<0.05$ was considered statistically significant. Statistical analysis was carried out according to student's t test. Statistical analyses were carried out using the SPSS ${ }^{\circledR}$ statistical software package (SPSS for Windows version 13.0, SPSS Inc., Chicago, Illinois, USA).

\section{Results}

Descriptive features of study subjects are shown in Table 1. As it can be seen in the table, mean age of patients with primary and metastatic hepatic carcinoma was close to that of control subjects. Of subjects in the patient group, 26 had metastatic hepatic cancer, while 14 had primary hepatic cancer.

Carbonic anhydrase (CA) and catalase (CAT) enzyme levels and relevant statistical analyses of control subjects and patients with primary and metastatic hepatic cancer are shown in Table 2. As it can be seen in Table 2, carbonic anhydrase values were higher in patients with primary and metastatic hepatic cancer in comparison with that of control subjects. In addition, in the group of metastatic hepatic cancer, serum CA level was significantly higher than that of primary hepatic cancer group. Moreover, in comparison with the control group, catalase (CAT) level was low in the primary and metastatic hepatic cancer groups. There was no significant difference between the primary hepatic cancer group and the metastatic hepatic cancer group with respect to CAT level $(\mathrm{P}>0.05)$.

Trace element and heavy metal levels and relevant statistical analyses of control subjects and patients with primary and metastatic hepatic cancer are shown in Table 3. It was observed that in comparison with the control group, serum iron $(\mathrm{Fe})$, cobalt $(\mathrm{Co})$, cadmium $(\mathrm{Cd})$ and

Table 1. Descriptive features of control subject and patients with liver cancer.

\begin{tabular}{cccc}
\hline & $\begin{array}{c}\text { Number of } \\
\text { male subject }\end{array}$ & $\begin{array}{c}\text { Number of } \\
\text { female subject }\end{array}$ & Mean age \\
\hline $\begin{array}{c}\text { Primary hepatic } \\
\text { cancer }\end{array}$ & 10 & 4 & $45-65$ \\
$\begin{array}{c}\text { Metastatic } \\
\text { hepatic cancer } \\
\text { Control group }\end{array}$ & 19 & 7 & $45-65$ \\
\hline
\end{tabular}

Table 2. Catalase and carbonic anhydrase enzyme activity levels in primary and metastatic hepatic cancer patients and control subjects.

\begin{tabular}{cccc}
\hline & $\begin{array}{c}\text { Primary } \\
(\mathrm{n}=14)\end{array}$ & $\begin{array}{c}\text { Metastatic } \\
(\mathrm{n}=26)\end{array}$ & $\begin{array}{c}\text { Control } \\
(\mathrm{n}=29)\end{array}$ \\
\hline $\mathrm{CA}(\mathrm{EU} / \mathrm{gHb})$ & $0.452 \pm$ & $1.161 \pm$ & $0.111 \pm$ \\
& $0.0368 \mathrm{a}^{*}$ & $0.0401 \mathrm{~A}$ & 0.00806 \\
$\mathrm{CAT}(\mathrm{EU} / \mathrm{gHb})$ & $16.094 \pm$ & $13.599 \pm$ & $61.480 \pm$ \\
& $1.774 \mathrm{~b}$ & $0.516 \mathrm{~B}$ & 0.210 \\
\hline
\end{tabular}

"Values are expressed as mean and $( \pm)$ standard error. ${ }^{*}$ It implies the statistical significance between primary and metastatic hepatic cancer patients ( $\mathrm{P}$ $<0.0005)$. ( $\mathrm{a}, \mathrm{b})$ Statistical significance between primary hepatic cancer patients and control subjects $(\mathrm{P}<0.005)$. (A, B) Statistical significance between metastatic hepatic cancer patients and control subjects $(\mathrm{P}<0.005)$. 
Table 3. Some mineral, trace element and heavy metal levels in primary and metastatic hepatic cancer patients and control subjects.

\begin{tabular}{cccc}
\hline & Primary $(\mathrm{n}=14)$ & Metastatic $(\mathrm{n}=26)$ & Control $(\mathrm{n}=29)$ \\
\hline $\mathrm{Fe}(\mu \mathrm{g} / \mathrm{dI})$ & $0.917 \pm 0.182 \mathrm{c}$ & $0.49 \pm 0.0311 \mathrm{C}$ & $0.0871 \pm 0.009$ \\
$\mathrm{Mg}(\mu \mathrm{g} / \mathrm{dI})$ & $11.711 \pm 0.567 \mathrm{~d}^{*}$ & $6.044 \pm 0.114 \mathrm{D}$ & $23.877 \pm 0.418$ \\
$\mathrm{Mn}(\mu \mathrm{g} / \mathrm{dI})$ & $0.047 \pm 0.003 \mathrm{e}$ & $0.0642 \pm 0.00454 \mathrm{E}$ & $0.253 \pm 0.012$ \\
$\mathrm{Zn}(\mu \mathrm{g} / \mathrm{dI})$ & $0.917 \pm 0.083 \mathrm{f}^{*}$ & $0.0455 \pm 0.0102 \mathrm{~F}$ & $2.243 \pm 0.0339$ \\
$\mathrm{Cu}(\mu \mathrm{g} / \mathrm{dI})$ & $0.953 \pm 0.068 \mathrm{~g}^{*}$ & $2.348 \pm 0.032 \mathrm{G}$ & $3.231 \pm 0.0487$ \\
$\mathrm{Co}(\mu \mathrm{g} / \mathrm{dI})$ & $0.024 \pm 0.004 \mathrm{~h}^{*}$ & $0.211 \pm 0.0112 \mathrm{H}$ & $0.00571 \pm 0.000317$ \\
$\mathrm{Cd}(\mu \mathrm{g} / \mathrm{dI})$ & $0.004 \pm 0.00072 \mathrm{k}^{*}$ & $0.0619 \pm 0.00496 \mathrm{~K}$ & $0.00056 \pm 0.00004$ \\
$\mathrm{~Pb}(\mu \mathrm{g} / \mathrm{dI})$ & $0.273 \pm 0.035 \mathrm{~m}^{*}$ & $0.937 \pm 0.020 \mathrm{M}$ & $0.0587 \pm 0.018$ \\
\hline
\end{tabular}

\#Values are expressed as mean and $( \pm)$ standard error. ${ }^{*}$ It implies the statistical significance between primary and metastatic hepatic cancer patients $(\mathrm{P}<0.0005)$. (c, d, e, f, h, k, m) It implies the statistical significance between primary hepatic cancer patients and the control subjects $(\mathrm{P}<0.005)$. (C, D, E, F, G, H, K, M) It implies the statistical significance between metastatic hepatic cancer patients and the control subjects $(\mathrm{P}<0.005)$.

lead $(\mathrm{Pb})$ levels were high in primary and metastatic hepatic cancer groups, while serum magnesium $(\mathrm{Mg})$, manganese $(\mathrm{Mn})$, Zinc $(\mathrm{Zn})$ and Copper $(\mathrm{Cu})$ levels were low $(\mathrm{P}<0.05)$ (Table 3).

\section{Discussion}

The current study was conducted to determine cytosolic erythrocyte carbonic anhydrase and catalase enzyme activities and levels of some trace elements and heavy metals.

Free radicals can be produced due to many reasons, including ultraviolet rays, metal-catalyzed reactions and atmospheric pollution [24]. It is known that free radicals have effects on occurrence and growth of cancer [25]. Anti-oxidant substance, including catalase, eliminates free radicals, resulting with alleviation of cellular damage and in conclusion, it may prevent or delay occurrence of cancer, aging and chronic diseases. $[25,26]$. Bellisola et al. (1987) found that catalase enzyme activity was low in tumor tissue of patients with HCC and in the light of this finding, they suggested that the anti-oxidant system was impaired in liver cancer [27]. In another study investigating CAT levels in a total of 125 patients with lung, lymphoma, breast and head and neck cancers, it was found that the CAT level was lower in all types of cancers, particularly in lymphoma, in comparison with the control group [28]. Lin and Yin (2007) examined CAT and SOD (superoxide dismutase) levels in 40 patients (age range: 37 - 80 years) who had recently diagnosed hepatocellular carcinoma and had no history of previous medical treatment, and they found that CAT and SOD activity levels were significantly low in the patient group [29]. Similar to those studies, our study also determined that catalase enzyme activity significantly de- creased in both primary hepatic cancer and metastatic hepatic cancer groups. In contrast, there was no statistically significant difference between the primary hepatic cancer group and the metastatic hepatic cancer group ( $\mathrm{P}$ $>0.05$; Table 2). Erythrocyte catalase activity can possibly be an indicator of oxidative stress. The balance between pro-oxidant and anti-oxidant substances impairs in cancer patients, resulting in oxidative stress and cellular damage. Low erythrocyte catalase activity in hepatic cancer may be an indicator of deficiency in the anti-oxidant system of cancer patients.

Some studies had determined that carbonic anhydrases played a significant role in malignant cerebral tumors and gastric and pancreatic cancers [11]. The enzymes of the carbonic anhydrase family play an important role in extracellular acidification, and several studies have suggested that the acidic environment facilitates and promotes tumor growth [30]. A study examined cytosolic erythrocyte CA (I, II) levels in various types of cancers (stomach, prostate, lung, ovary), and it was found that the CA level was higher in the cancer group in comparison with the control group [31]. In another study examining CA levels in hematologic diseases, particularly leukemia, it was noted that in comparison with the control group, CA (I, II) levels were higher in the patient group [30]. In the current study, CA values were higher in patients with primary and metastatic hepatic cancer in comparison with the control subjects. The difference was statistically significant $(\mathrm{P}>0.05)$. In addition, in the group of metastatic hepatic cancer, the serum CA level was higher than that of primary hepatic cancer group $(\mathrm{P}<0.05$; Table 2$)$. We did not have the opportunity to make comparisons since we could not find another study examining erythrocyte CA level in liver cancer. However, higher cytosolic erythrocyte CA level in patients with liver cancer is 
suggestive of the possibility that this enzyme may play a significant role in pathophysiology and diagnosis of liver cancer. However, larger studies are required in order to completely understand how the enzyme level will change depending on type of cancer or stage.

Magnesium $(\mathrm{Mg})$ is a macro-element with anti-oxidant effects, which participates to more than 300 anti-oxidative enzymatic reactions [32]. In association with oxidative stress, magnesium deficiency plays a role in aging and the occurrence of geriatric diseases. Although the relation cannot be clearly evidenced in human, it was shown that $\mathrm{Mg}$ deficiency promotes oxidative stress in experimental animals [33]. In a study examining many macro-elements and trace elements, cancer patients were compared with healthy subjects and it was found that the serum $\mathrm{Mg}$ level was lower in the cancer group. Low serum $\mathrm{Mg}$ level can be secondary to the fact that the element is consumed in some metabolic pathways or replaced with carcinogenic metals in the occurrence and growth of cancer [34]. In the current study, similar to findings written above, serum $\mathrm{Mg}$ levels were significantly lower in patients with primary and metastatic hepatic cancer in comparison with the control subjects $(\mathrm{P}<$ 0.05). In addition, in the group of metastatic hepatic cancer, serum Mg level was lower than that of the primary hepatic cancer group (Table 3).

Copper $(\mathrm{Cu})$ plays a role in the production of free oxygen radicals, which damage cellular organelles [35] Thus, excess $\mathrm{Cu}$ leads to hepatic damage and facilitates the occurrence of cancer. Several studies found that in HCC patients $\mathrm{Cu}$ level was higher in tumor tissue in comparison with the surrounding tissue [36]. In contrast, some studies reported that $\mathrm{Cu}$ level was lower in the tumor tissue of patients with metastatic liver cancer in comparison with normal hepatic tissue [37]. In the current study, the serum $\mathrm{Cu}$ level was lower in patients with primary and metastatic hepatic cancer in comparison with the control subjects $(\mathrm{P}<0.05)$. In addition, in the group of primary hepatic cancer, the serum $\mathrm{Cu}$ level was lower than that of the metastatic group $(\mathrm{P}<0.05$; Table 3).

Manganese (Mn) plays an important role as cofactor of many enzymes [38]. Manganese is a trace element, which is necessary for the activity of SOD enzyme, an important member of the anti-oxidant system [39]. In the current study, the serum Mn level was lower in patients with primary and metastatic hepatic cancer in comparison with healthy subjects $(\mathrm{P}<0.05)$. In addition, in the primary group, Mn level was lower than that of the metastatic group, but the different was not statistically significant ( $>$ > 0.05; Table 3). Low Mn level may impair the balance between oxidant and anti-oxidant substances and it may also weaken the anti-oxidant system. In a study evaluating serum trace element levels and total anti-oxidant status in patients with breast cancer, authors found that the Mn level was significantly lower in the patient group in comparison with the control group [40]. Takikawa (1990) determined that serum Mn levels did not vary between patients with $\mathrm{HCC}$ and control subjects [41].

Iron $(\mathrm{Fe})$ plays a role in the transportation of oxygen, ATP production and DNA synthesis. In addition, it is included in the prosthetic group of the catalase enzyme [42]. Free forms of Fe may exert toxic effects in viable cells. The toxicity may lead to the production of active oxygen species, resulting in the promotion of lipid peroxidation and attacks on DNA molecules [43]. In the current study, the serum Fe level was significantly higher in patients with primary and metastatic hepatic cancer in comparison with the control group $(\mathrm{P}<0.05)$. In contrast, there was no statistically significant difference between the primary hepatic cancer group and metastatic hepatic cancer group ( $\mathrm{P}>0.05$; Table 3$)$. It can be speculated that high Fe level is an important factor in the occurrence of liver cancer, since it may result in oxidative damage. Another study found that the Fe level was lower in the tumor tissue of patients with primary liver cancer in comparison with normal surrounding tissue [44]. Feng et al. (2012) conducted a study on patients with breast cancer and similar to the findings of the current study, they determined that the serum $\mathrm{Fe}$ level was higher in comparison with the control group. In the light of this finding, they suggested the view that a high serum Fe level can be a risk factor for breast cancer [40].

Zinc (Zn) protects sulfhydryl groups of proteins against attacks of free radicals and it decreases the production of free radicals by inhibiting redox-active transition metals $(\mathrm{Fe}, \mathrm{Cu})$ [45]. A study was conducted to evaluate levels of trace elements in tumor tissue of patients with metastatic liver cancer and it was found that $\mathrm{Zn}$ level was lower in tumoral tissue in comparison with the tissue surrounding the tumor and the control group [37]. Some studies were performed in patients with HCC, tumor tissue levels of $\mathrm{Zn}$, were found to be lower than the surrounding tissues [46]. In the current study, the serum $\mathrm{Zn}$ level was lower in patients with primary and metastatic hepatic cancer in comparison with healthy subjects $(\mathrm{P}<0.05)$. In addition, in the metastasis group, the serum $\mathrm{Zn}$ level was lower than that of the primary group $(\mathrm{P}<0.05$; Table 3$)$. Although it is thought that levels of zinc are low in cancer due to oxidative stress or cellular use of zinc and changes in secretion, the mechanism could not be completely clarified [47].

In the occurrence or growth of cancer, the role of cobalt (Co) compounds is not clearly clarified. Although there is no definitive evidence indicating that Co compounds lead to cancer in humans, animal studies proved that cobalt powders (Cobalt oxide and Cobalt sulphide) 
lead to the occurrence of cancer [48]. Pasha et al. (2008) determined that there was no statistically significant difference between the group of cancer patients and the control group with respect to Co level [34]. Another study examined some trace elements and vitamins in 20 patients with prostate cancer and found that serum Co level was higher in the group of cancer patients relative to the control group [49]. In the current study, serum Co level was higher in patients with primary and metastatic hepatic cancer in comparison with the control group $(\mathrm{P}<$ $0.05)$. In addition, in the group of metastatic hepatic cancer, serum Co level was higher than that of primary hepatic cancer group. There was statistically significant difference between groups ( $\mathrm{P}<0.05$; Table 3$)$. Further studies are needed to better understand potential hazards of cobalt on human whether leads to cancer.

Cadmium has been designated a human carcinogen by the IARC (International Agency for Research on Cancer) [50]. Cadmium exerts many effects, via multiple mechanisms of action, on the development of cancer. Some of these include oxidative stress, prevention of DNA repair and inhibition of apoptosis [51]. Cadmium is taken in foods, air and respiration in small amounts and it accumulates in the body over time [52]. Primary deposition sites are the liver and kidneys. In addition, the element may accumulate in the pancreas, prostate and heart [53]. In the current study, serum Cd level was significantly higher in patients with primary and metastatic hepatic cancer in comparison with the control group $(\mathrm{P}<0.05)$. In addition, in the metastasis group, serum $\mathrm{Cd}$ level was higher than that of the primary hepatic cancer group $(\mathrm{P}<$ 0.05; Table 3). Armstrong and Kazantzis (1985) found that the frequency of kidney diseases increased in workers who were exposed to cadmium, and the severity of the disease was related to exposure time and dose, while frequency of prostate cancer mildly increased (although not statistically significant) in workers who were exposed to cadmium at moderate or high level [54]. Another study examined 112 female and male patients with cancer and found that serum $\mathrm{Cd}$ level was 1.6- to 7.4-folds higher in cancer patients in comparison with that of the control group. High level of toxic metals, such as $\mathrm{Cd}$, in cancer patients (in comparison with healthy subjects) indicates that those metals accumulate in the body and replace macroelements [34].

IARC classified lead $(\mathrm{Pb})$ as Group 2A carcinogenic substance [55]. It is known that exposure to lead results in cell proliferation in the liver, but the relation of this finding with hepatic tumors could not be proven [56]. A cohort study was conducted in Sweden on lead smelter workers, who have occupational exposure to lead, and cancer rates were examined; it was determined that some types of cancers, particularly lung cancer, were more common in those workers [57]. A study enrolled 154 newly diagnosed patients with renal cancer and it was concluded that the serum $\mathrm{Pb}$ level was higher in the patient group relative to the control group and a high serum lead level was related to the onset of renal cancer [58]. Similar to that study, the serum $\mathrm{Pb}$ level was higher in patients with primary and metastatic hepatic cancer in comparison with healthy subjects in the current study ( $\mathrm{P}$ $<0.05)$. In addition, in the metastasis group, the serum $\mathrm{Pb}$ level was higher than that of primary group $(\mathrm{P}<0.05$; Table 3). In the light of these results, it can be speculated that environmental exposure of lead is a risk factor for some types of cancers, including liver cancer.

\section{Conclusion}

In conclusion, levels of trace elements vary in many types of cancers. Further studies are required to better understand the reasons and underlying mechanisms. Lower catalase activity in cancer patients raises a question. Is it the lower catalase activity that leads to the occurrence of cancer or does the anti-oxidant defense system become weaker in the process of the development of cancer? Further studies with larger populations are required to answer this question. Carbonic anhydrase isoenzymes have come to be of interest, since some recent studies found that some iso-enzymes of carbonic anhydrase were higher in some types of cancers. However, available studies are extremely limited, and the relation between cancer and carbonic anhydrase could not be clearly clarified. Higher erythrocyte carbonic anhydrase levels in patients with hepatic cancer suggest that the enzyme can be a useful indicator in the diagnosis of the cancer and this indicator may direct treatment of cancer. However, larger studies should be conducted on this issue.

\section{REFERENCES}

[1] R. Mazzanti, L. Gramantieri and L. Bolondi, "Hepatocellular Carcinoma: Epidemiology and Clinical Aspects," Molecular Aspects of Medicine, Vol. 29, No. 1-2, 2008, pp. 130-143.

http://dx.doi.org/10.1016/j.mam.2007.09.008

[2] C. Müller, "Hepatocellular Carcinoma-Rising İncidence, Changing Therapeutic Strategies," Wiener Medizinische Wochenschrift, Vol. 156, No. 13-14, 2008, pp. 404-409. http://dx.doi.org/10.1007/s10354-006-0316-3

[3] H. Varolgüneş, A. İnan, E. Kaptanoğlu and S. Demirci, "Methods of Treatment Primary and Metastatic Liver Tumors," Journal of Ankara University Faculty of Medicine, Vol. 50, No. 4, 1997, pp. 209-230.

[4] E. Göksoy and M. Kapan, "Primary Malignant Tumors of the Liver. Hepato-Biliary System and Pancreas Diseases," Symposium Series, Vol. 28, 2002, pp. 159-182.

[5] B. Haliwell and J. Gutteridge, "Oxygen İs Poisonous: An 
İntroduction to Oxygen Toxicity and Free Radicals," In: B. Halliwell and J. Gutteridge, Eds., Free Radicals in Biology and Medicine, Clarendon Press, Oxford, 1989, pp. 121.

[6] C. E. Cross, B. Halliwell and E. T. Borish, "Oxygen Radicals and Human Disease," Annals of Internal Medicine, Vol. 107, No. 4, 1987, pp. 526-545. http://dx.doi.org/10.7326/0003-4819-107-4-526

[7] K. Asayama, T. Nakane and H. Uchida, "Serum Antioxidant Status in Streptazosin-İnduced Diabetic Rat," Hormone and Metabolic Research, Vol. 26, 1994, pp. 617-620. http://dx.doi.org/10.1055/s-2007-1001693

[8] C. Lindholm, A. Acheva and S. Salomaa, "Clastogenic Plasma Factors: A Short Overview," Radiation and Environmental Biophysics, Vol. 49, No. 2, 2010, pp. 133-138. http://dx.doi.org/10.1007/s00411-009-0259-3

[9] C. T. Supuran and A. Scozzafava, "Carbonic Anhydrase İnhibitors," Current Medicinal Chemistry-Immunology, Endocrine \& Metabolic Agents, Vol. 1, No. 1, 2001, pp. 61-97. http://dx.doi.org/10.2174/1568013013359131

[10] D. Hewett-Emmett and R. E. Tashian, "Functional Diversity, Conservation, and Convergence in the Evolution of the [Alpha]-, [Beta]-, and [Gamma]-Carbonic Anhydrase Gene Families," Molecular Phylogenetics and Evolution, Vol. 5, No. 1, 1996, pp. 50-77.

http://dx.doi.org/10.1006/mpev.1996.0006

[11] S. Parkkila, A. K. Parkkila, T. Juvonen, V. P. Lehto and H. Rajaniemi, "Immunohistochemical Demonstration of the Carbonic Anhydrase İsoenzymes I and II in Pancreatic Tumors," The Histochemical Journal, Vol. 27, No. 2, 1995, pp. 133-138. http://dx.doi.org/10.1007/BF00243908

[12] W. R. Chegwidden, S. J. Dodgson and I. M. Spencer, "The Roles of Carbonic Anhydrase in Metabolism, Cell Growth and Cancer in Animals," In: W. R. Chegwidden, N. D. Carter and Y. H. Edwards, Eds., The Carbonic Anhydrases, Birkhauser Verlag New Horizons, Basel, 2000, pp. 343-361.

[13] A. Nogradi, "The Role of Carbonic Anhydrases in Tumors," American Journal of Pathology, Vol. 153, No. 1, 1998, pp. 1-4. http://dx.doi.org/10.1016/S0002-9440(10)65537-X

[14] W. Merz, "The Essential Trace Elements," Science, Vol. 213, No. 4514, 1981, pp. 1332-1338. http://dx.doi.org/10.1126/science.7022654

[15] E. Mandishona, A. P. MacPhail, V. R. Gordeuk, M. A. Kedda, A. C. Paterson, T. A. Rouault and M. C. Kew, "Dietary İron Overload as a Risk Factor for Hepatocellular Carcinoma in Black Africans," Hepatology, Vol. 27, No. 6, 1998, pp. 1563-1566. http://dx.doi.org/10.1002/hep.510270614

[16] A. Barbouti, P. T. Doulias, B. Z. Zhu, B. Frei and D. Galaris, "Intracellular İron, But Not Copper, Plays a Critical Role in Hydrogen Peroxide-İnduced DNA Damage," Free Radical Biology \& Medicine, Vol. 31, No. 4, 2001, pp. 490-498. http://dx.doi.org/10.1016/S0891-5849(01)00608-6

[17] K. T. Suzuki, M. Rui, J. Ueda and T. Ozawa, "Production of Hydroxyl Radicals by Copper-Containing Metallothio- nein: Roles as Prooxidant," Toxicology and Applied Pharmacology, Vol. 141, No. 1, 1996, pp. 231-237.

[18] B. Halliwell and J. M. Gutteridge, "Oxygen Toxicity, Oxygen Radicals, Transition Metals and Diseases," Biochemical Journal, Vol. 219, No. 1, 1984, pp. 1-14.

[19] A. Goel, V. Dani and D. K. Dhawan, "Protective Effects of Zinc on Lipid Peroxidation, Antioxidant Enzymes Hepatic Histoarchitecture in Chlorpyrifos-İnduced Toxicity," Chemico-Biological Interactions, Vol. 156, No. 2-3, 2005, pp. 131-140.

http://dx.doi.org/10.1016/j.cbi.2005.08.004

[20] M. Waisberg, P. Joseph, B. Hale and D. Beyersmann, "Molecular and Cellular Mechanisms of Cadmium Carcinogenesis," Toxicology, Vol. 192, No. 2-3, 2003, pp. 95117. http://dx.doi.org/10.1016/S0300-483X(03)00305-6

[21] S. Gwin1, E. Macfarlane, A. Del Monaco, D. Mclean, D. Pisaniello, G. P. Benke and M. Ross Sim, "Cancer Incidence, Mortality, and Blood Lead Levels among Workers Exposed to Inorganic Lead," Annals of Epidemiology, Vol. 22, No. 4, 2012, pp. 270-276. http://dx.doi.org/10.1016/j.annepidem.2012.01.003

[22] T. H. Maren, "Carbonic Anhydrase, Chemistry, Physiology and İnhibition," Physiological Reviews, Vol. 47, No. 4, 1967, pp. 595-781.

[23] H. Aebi, "Catalase in Vitro. Methods of Enzymatic Analysis," Academic Press, New York and London, 1974, pp. 673-676. http://dx.doi.org/10.1016/B978-0-12-091302-2.50032-3

[24] E. Cadenas, "Biochemistry of Oxygen Toxicity," Annual Review of Biochemistry, Vol. 58, 1989, pp. 79-110. http://dx.doi.org/10.1146/annurev.bi.58.070189.000455

[25] Y. Sun, "Free Radicals, Antioxidant Enzymes and Carcinogenesis," Free Radical Biology \& Medicine, Vol. 8, No. 6, 1990, pp. 583-599. http://dx.doi.org/10.1016/0891-5849(90)90156-D

[26] M. José, J. M. Matés, J. M Segura, C. Pérez-Gómez, R. Rosado, L. Olalla, et al., "Antioxidant Enzymatic Activities in Human Blood Cells after an Allergic Reaction to Pollen Or House Dust Mite," Blood Cells, Molecules and Diseases, Vol. 25, No. 2, 1999, pp. 103-109. http://dx.doi.org/10.1006/bcmd.1999.0234

[27] G. Bellisola, M. Casaril, G. B. Gabrielli, M. Caraffi and R. Corrocher, "Catalase Activity in Human Hepatocellular Carcinoma (HCC)," Clinical Biochemistry, Vol. 20, No. 6, 1987, pp. 415-417. http://dx.doi.org/10.1016/0009-9120(87)90007-5

[28] A. Casado, R. Torre, M. E. Lopez-Fernandez, D. Carrascosa, M. C. Casado and M. V. Ramirez, "Superoxide Dismutase and Catalase Blood Levels in Patients with Malignant Diseases," Cancer Letters, Vol. 93, No. 2, 1995, pp. 187-192. http://dx.doi.org/10.1016/0304-3835(95)03808-A

[29] C. C. Lin and M. C. Yin, "B Vitamins Deficiency and Decreased Anti-Oxidative State in Patients with Liver Cancer," European Journal of Nutrition, Vol. 46, No. 5, 2007, pp. 293-299.

http://dx.doi.org/10.1007/s00394-007-0665-8 
[30] G. Bonapacea, F. Iuliano, S. Molica, A. Peta and P. Strisciuglio, "Cytosolic Carbonic Anhydrase Activity in Chronic Myeloid Disorders with Different Clinical Phenotype," Biochimica et Biophysica Acta, Vol. 1689, No. 3, 2004, pp. 179-181. http://dx.doi.org/10.1016/j.bbadis.2004.05.003

[31] Ö. Özensoy, F. Koçkar, O. Arslan, S. Isık, C. T. Supuran and M. Lyon, "An Evaluation of Cytosolic Erythrocyte Carbonic Anhydrase and Catalase in Carcinoma Patients: An Elevation of Carbonic Anhydrase Activity," Clinical Biochemistry, Vol. 39, No. 8, 2006, pp. 804-809. http://dx.doi.org/10.1016/j.clinbiochem.2006.03.001

[32] N. Hasebe, "Oxidative Stress and Magnesium," Clinical Calcium, Vol. 15, No. 2, 2005, pp. 194-202.

[33] Y. Manuel, B. Keenoy, G. Moorkens, J. Vertommen, M. Noe, J. Neve and I. De Leeuw, "Magnesium Status and Parameters of the Oxidant Balance in Patients with Chronic Fatigue: Effect of Suplementation with Magnesium," Journal of the American College of Nutrition, Vol. 19, No. 3, 2000, pp. 374-382. http://dx.doi.org/10.1080/07315724.2000.10718934

[34] Q. Pasha, S. A. Malik and M. H. Shah, "Statistical Analysis of Trace Metals in the Plasma of Cancer Patients versus Controls," Journal of Hazardous Materials, Vol. 153, No. 3, 2008, pp. 1215-1221. http://dx.doi.org/10.1016/j.jhazmat.2007.09.115

[35] R. Seth, S. Yang, S. Choi, M. Sabean and E. A. Roberts, "In Vitro Assessment of Copper-İnduced Toxicity in the Human Hepatoma Line, Hep G2," Toxicol in Vitro, Vol. 18 , No. 4, 2004, pp. 501-509. http://dx.doi.org/10.1016/j.tiv.2004.01.006

[36] M. Ebara, H. Fukuda, R. Hatano, M. Yoshikawa, N. Sugiura, H. Saisho, F. Kondo and M. Yukawa, "Metal Contents in the Liver of Patients with Chronic Liver Disease Caused by Hepatitis C Virus. Reference to Hepatocellular Carcinoma," Oncology, Vol. 65, No. 4, 2003, pp. 323-330. http://dx.doi.org/10.1159/000074645

[37] A. Roguljic, A. Roth, K. Kolaric and Z. Maricic, "Iron, Copper, and Zinc Liver Tissue Levels in Patients with Malignant Lymphomas," Cancer, Vol. 46, No. 3, 1980, pp. 565-569. http://dx.doi.org/10.1002/1097-0142(19800801)46:3<565 ::AID-CNCR2820460324>3.0.CO;2-N

[38] R. M. Leach, "Role of Manganese in Mucopolysaccharide Metabolism," Federation Proceedings, Vol. 30, No. 3, 1971, pp. 991-994.

[39] S. Johnson, "The Possible Crucial Role of İron Accumulation Combined with Low Tryptophan, Zinc and Manganese in Carcinogenesis," Medical hypotheses, Vol. 57, No. 5, 2001, pp. 539-543. http://dx.doi.org/10.1054/mehy.2001.1361

[40] J. F. Feng, L. Lu, P. Zeng, Y. H. Yang, J. Luo, Y. W. Yang and D. Wang, "Serum Total Oxidant/Antioxidant Status and Trace Element Levels in Breast Cancer Patients," International Journal of Clinical Oncology, Vol. 17, No. 6, 2012, pp. 575-583. http://dx.doi.org/10.1007/s10147-011-0327-y

[41] S. Takikawa, "Changes in Serum $\mathrm{Zn}, \mathrm{Cu}, \mathrm{Se}$, and $\mathrm{Mn}$
Levels in Patients with Chronic Liver Diseases and Hepatocellular Carcinoma," Journal of Clinical Biochemistry Nutrition, Vol. 8, No. 2, 1990, pp. 153-164. http://dx.doi.org/10.3164/jcbn.8.153

[42] B. Desoize, "Metals and Metal Compounds in Carcinogenesis," In Vivo, Vol. 17, No. 6, 2003, pp. 529-539.

[43] D. D. Miller, "Minerals," In: O. R. Fennema, Ed., Food Chemistry, Marcel Dekker, New York, 1996, pp. 617649.

[44] T. Maeda, M. Shimada, N. Harimoto, E. Tsujita, S. Maehara, T. Rikimaru, S. Tanaka, K. Shirabe and Y. Maehara, "Role of Tissue Trace Elements in Liver Cancers and Non-Cancerous Liver Parenchyma," Hepatogastroenterology, Vol. 52, No. 61, 2005, pp. 187-190.

[45] M. Valko, C. J. Rhodes, J. Moncola, M. Izakovic and M. Mazur, "Free Radicals, Metals and Antioxidants in Oxidative Stress-Induced Cancer," Chemico-Biological Interactions, Vol. 160, No. 1, 2006, pp. 1-40. http://dx.doi.org/10.1016/j.cbi.2005.12.009

[46] K. Y. Liaw, P. H. Lee, F. C. Wu, J. S. Tsai, S. Y. LinShiau, "Zinc, Copper, and Superoxide Dismutase in Hepatocellular Carcinoma," The American Journal of Gastroenterology, Vol. 92, No. 12, 1997, pp. 2260-2263.

[47] P. W. Keeling, W. Ruse, J. Bull, B. Hannigan and R. P. Thompson, "Direct Measurement of the Hepatointestinal Extraction of Zinc in Cirrhosis and Hepatitis," Clinical Science, Vol. 61, No. 4, 1981, pp. 441-444.

[48] G. Kazantzis, "Role of Cobalt, Iron, Lead, Manganese, Mercury, Platinum, Selenium and Titanium in Carcinogenesis," Environmental Health Perspectives, Vol. 40, 1981, pp. 143-161.

[49] H. Özmen, F. A. Erulaş, F. Karataş, A. Çukurovalı and O. Yalçın, "Comparison of the Concentration of Trace Metals (Ni, Zn, Co, Cu and Se), Fe, Vitamins A, C and E, and Lipid Peroxidation in Patients with Prostate Cancer," Clinical Chemistry Laboratory Medicine, Vol. 44, No. 2 , 2006, pp. 175-179. http://dx.doi.org/10.1515/CCLM.2006.032

[50] International Agency for Research on Cancer Monographs, "Beryllium, Cadmium, Mercury and Exposures in the Glass Industry, Vol. 58," International Agency for Research on Cancer, Lyon, 1993, pp. 119-238.

[51] P. Joseph, "Mechanisms of Cadmium Carcinogenesis," Toxicology and Applied Pharmacology, Vol. 238, No. 3, 2009, pp. 272-279. http://dx.doi.org/10.1016/j.taap.2009.01.011

[52] O. Lahelma, M. Nuurtamo, A. Paaso, L. Rasanen, E. Saari and P. Varo, "Mineral Element Composition of Finnish Food: N, K, Ca, Mg, P, S, Fe, Cu, Mn, Zn, Mo, $\mathrm{Co}, \mathrm{Ni}, \mathrm{Cr}, \mathrm{F}, \mathrm{Se}, \mathrm{Si}, \mathrm{Rb}, \mathrm{Al}, \mathrm{B}, \mathrm{Br}, \mathrm{Hg}, \mathrm{As}, \mathrm{Cd}, \mathrm{Pb}$ and Ash," Acta Agriculture Scandinavia, Vol. 22, 1980, p. 171.

[53] I. Bremner, "Mammalian Absorption, Transport and Excretion of Cadmium," In: M. Webb, Ed., Chemistry, Biochemistry and Biology of Cadmium, Elsevier/NorthHolland Biomedical Press, Amsterdam, 1979, pp. 175-193.

[54] B. G. Armstrong and G. Kazantzis, "Prostatic Cancer and 
Chronic Respiratory and Renal Disease in British Cadmium Workers: A Case-Control Study," British Journal of Industrial Medicine, Vol. 42, No. 8, 1985, pp. 540545.

[55] IARC, "Inorganic and Organic Lead Compounds," IARC Monograph, Vol. 87, France, 2006, pp. 10-17.

[56] E. K. Silbergeld, "Facilitative Mechanisms of Lead as a Carcinogen," Mutation Research, Vol. 533, No. 1-2, 2003, pp. 121-133. http://dx.doi.org/10.1016/j.mrfmmm.2003.07.010

[57] V. Englyst, N. G. Lundstroma, L. Gerhardsson, L. Rylander and G. Nordberg, "Lung Cancer Risks among
Lead Smelter Workers also Exposed to Arsenic," The Science of the Total Environment, Vol. 273, No. 1-3, 2001, pp. 77-82.

http://dx.doi.org/10.1016/S0048-9697(00)00843-3

[58] E. B. Southard, A. Roff, T. Fortugno, J. P. Richie, M. Kaag, V. M. Chinchilli, J. Virtamo, D. Albanes, S. Weinstein and R. T. Wilson, "Lead, Calcium Uptake, and Related Genetic Variants in Association with Renal Cell Carcinoma Risk in a Cohort of Male Finnish Smokers," Cancer Epidemiology Biomarkers \& Prevention, Vol. 21, No. 1, 2012, pp. 191-201.

http://dx.doi.org/10.1158/1055-9965.EPI-11-0670 